\title{
Man-biting Activity of Anopheles (Nyssorhynchus) albimanus and $A n$. (Kerteszia) neivai (Diptera: Culicidae) in the Pacific Lowlands of Colombia
}

\author{
Yezid Solarte, Camilo Hurtado*, Ranulfo Gonzalez**, Bruce Alexander*** \\ Instituto de Investigación y Desarrollo en Agua Potable, Saneamiento Básico y Conservación del Recurso \\ Hídrico (CINARA), Universidad del Valle, A.A.25157, Cali, Colombia* Instituto Nacional de Pesquisas da \\ Amazônia, Caixa Postal 478, Manaus, AM, Brasil ** Departamento de Biologia, Universidad del Valle, A.A. \\ 25360, Cali, Colombia *** Centro Internacional de Entrenamiento e Investigaciones Médicas (CIDEIM), \\ A.A. 5390, Cali, Colombia
}

The daily man-biting activity of Anopheles (Nyssorhynchus) albimanus and An. (Kerteszia) neivai was determined in four ecologically distinct settlements of the Naya River, Department of Valle, Colombia. Differences were found among the settlements with respect to the mosquito species present, intradomiciliary and extradomiciliary biting activity and population densities.

Key words: malaria - Anopheles (Nyssorhynchus) albimanus - Anopheles (Kerteszia) neivai - Anopheles (Anopheles) punctimacula - man-biting - mosquitoes - ecology - Colombia

The daily activity of mosquitoes is regulated by an endogenous circadian rhythm (Beck 1968) that may be affected by light, temperature and humidity (Murillo et al. 1988). This rhythm is species-specific and may explain why several Anopheles species that exist in the same habitat, may share food resources, resting sites and breeding sites by exploiting them at different times. Four Anopheles species (An. (Nyssorhynchus) albimanus Weidemann, An. (Kerteszia) neivai Howard, Dyar and Knab, An. (Anopheles) punctimacula Dyar and Knab and An. (Anopheles) apicimacula Dyar and Knab occur in the same habitat on the Naya River, within the city limits of Buenaventura, largest city of the Pacific Coast of Colombia (Hurtado \& Solarte, unpublished, Rengifo 1974). The first three species have been found naturally infected with Plasmodium (Rey et al. 1945, Huffaker et al. 1945, Herrera et al. 1987, Carvajal et al. 1989).

This article reports the results of a study to determine the human biting activity of $A n$. (Nys). albimanus and An. (Ker.) neivai and investigate whether their coexistence could be explained by temporal partitioning of blood meals, a necessary resource for their development.

\section{MATERIALS AND METHODS}

Field work was carried out on the lower Naya River, municipality of Buenaventura $\left(77^{\circ} 30^{\prime} \mathrm{N}\right.$, $3^{\circ} 25^{\prime} \mathrm{W}$ and $77^{\circ} 15^{\prime} \mathrm{N}, 3^{\circ} 10^{\prime} \mathrm{W}$ ) in the Depart-

This study was funded under a special program of the United Nations, WHO/TDR and World Bank.

Received 13 March 1995

Accepted 15 December 1995 ment of Valle, Colombia (Fig. 1). Four ecologically diverse localities (Concherito, Santa Cruz, El Trueno and La Concepción) were chosen based on a previous study (Solarte et al. 1994) in which active transmission of malaria was determined. The ecological characteristics of all four sites were also described in Solarte et al. (1994).

Concherito is a settlement of 33 houses at only $3 \mathrm{~m}$ above sea level surrounded by mangroves. It has a permanent population of 71 inhabitants, augmented by a transient population of fishermen from Buenaventura and other settlements of the Naya River. Forty-nine species of trees were found in the vicinity of Concherito, dominated by Euterpe cuatrecasana, Pelliciera rhizophorae and Pterocarpus officinalis. In addition the inhabitants of the settlement cultivate 12 different crop species.

Santa Cruz is situated in an ecologically transitional area between the mangroves and a range of low hills, parts of the area being flooded at high tide. These hills mark the limits of the humid tropical forest, the most abundant plant species being Geonoma and Wettinia spp. The settlement lies at approximately $10 \mathrm{~m}$ above sea level and has 77 houses with a permanent population of 166 residents, who subsist by fishing and cutting timber.

El Trueno lies within the area of low hills and is surrounded by forest that has been cleared to a considerable extent to provide timber and land for crops. It shows the highest diversity of tree species of any of the four sites (Solarte et al. 1994) including Wettinia, Jessenia and Miconia spp. This settlement has 127 houses and 278 residents, who live by clearing timber and subsistence farming. 


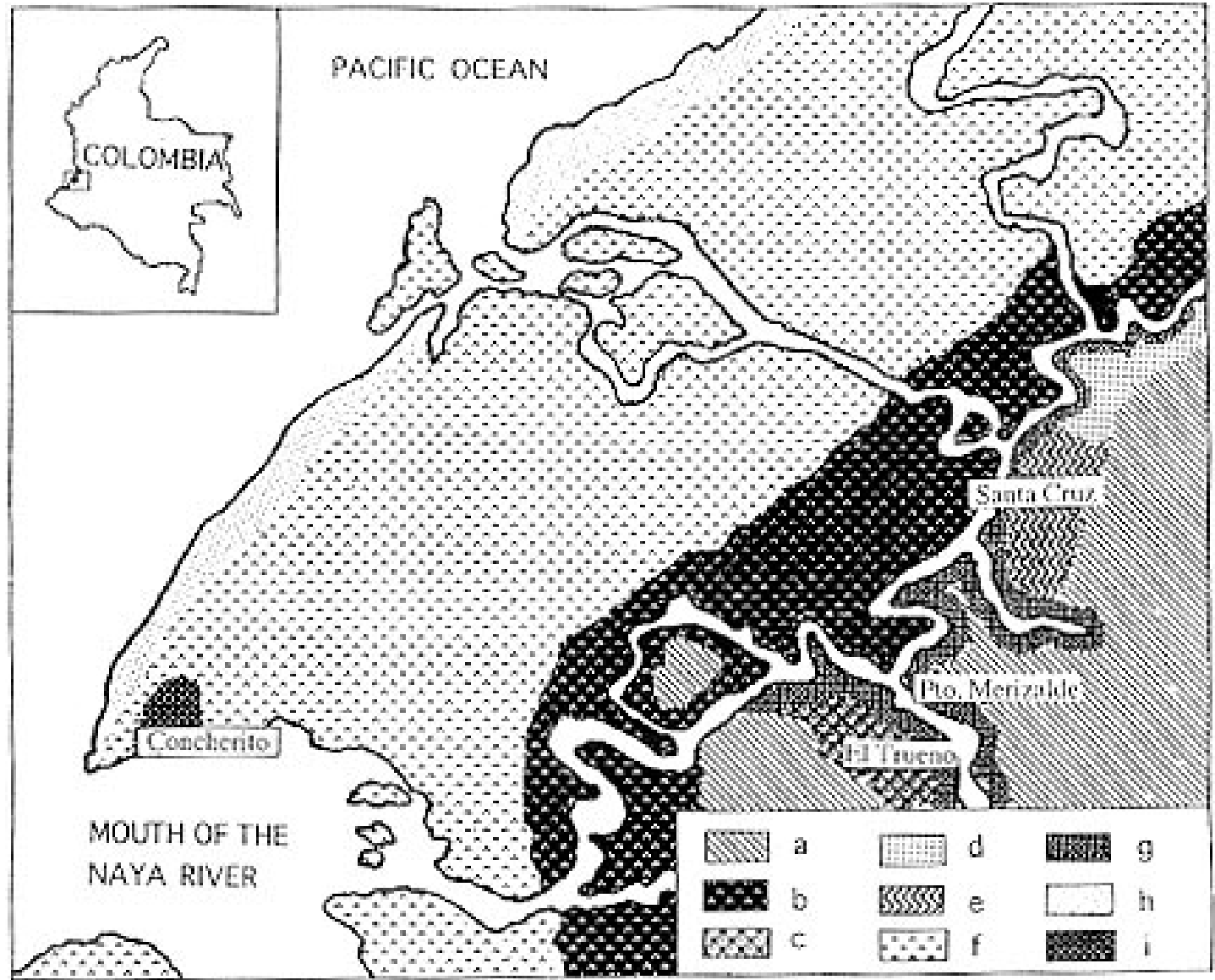

Fig. 1: types of vegetation cover on the lower Naya River. a - tropical humid forest on hills, b - mangrove/cuangarial, c cultivated areas/forest, d - Pelliciera-Euterpe rhizophorae, e - Euterpe-Pterocarpus-Symphonia, f - mangroves, g - cultivated areas (terraces), h - scrub/cultivated areas/forest, i - Euterpe-Pelliciera-Pterocarpus.

La Concepción is a settlement of 146 houses situated on the foothills of the Western Cordillera of the Andes and is surrounded by relatively undisturbed humid forest. Residents live by hunting and cutting timber, with some subsistence agriculture and gold mining.

Mosquito sampling was realized using humanbait inside and around houses and in the forest, following standard WHO recommendations (WHO 1975). Nocturnal sampling was carried out from 18:00 to 6:00 hr by two volunteers trading places between two consecutive six-hour shifts; 20 sampling sessions were made at each site for a total of $480 \mathrm{hr}$ at each site. Diurnal collections in the forest were made only at Santa Cruz and La Concepcion from 18:00 to 6:00 hr during three consecutive four-hour shifts; 5 sampling session were made for a total of $120 \mathrm{hr}$ per site. Mosquito identifications were made according to the keys of Cova and Sutil (1977), Faran (1980), Faran and Linthicum (1981) and Zavortink (1973).

\section{RESULTS}

Biting activity of mosquitoes on the lower Naya River is summarized in Table. Three species of Anopheles were encountered: An. (Nys) albimanus, An. (Ker) neivai and An. (Ano) punctimacula. These occured in different combinations and densities in each of the settlements. The first two species were found in Concherito and in El Trueno, while only An. (Ker) neivai was present in Santa Cruz and La Concepción. Only three individuals of An. (Ano) punctimacula were captured, all at El Trueno, in or near cultivated areas around the houses; individuals of this species were collected between 19:00-20:00 and 23:00-24:00 hr.

Man-biting activity of An. (Nys) albimanus in Concherito was first recorded at 18:00 hr and continued throughout the night, with a peak between 22:00-23:00 hr inside and around houses. Biting rates in houses and in the peridomicile during this peak were 36.3 and 67.7 bites/man-hr respectively. A second peak in peridomiciliary biting was de- 
TABLE

Summary of peaks (hr) in biting activity of Anopheles albimanus and An. neivai in four localities of the lower Naya River, Buenaventura

\begin{tabular}{|c|c|c|c|c|c|}
\hline \multirow[t]{2}{*}{ Species } & & \multicolumn{4}{|c|}{ Locality } \\
\hline & & Concherito & El Trueno & Santa Cruz & La Concepcíon \\
\hline \multirow[t]{3}{*}{ An. albimanus } & I & 22:00-23:00 & NR & NR & NR \\
\hline & $\mathrm{P}$ & 22:00-23:00 & 20:00-21:00 & NR & NR \\
\hline & $\mathrm{F}$ & $\begin{array}{c}12: 00-1: 00 \\
-\end{array}$ & - & NR & NR \\
\hline \multirow[t]{4}{*}{ An. neivai } & I & $18: 00-19: 00$ & $18: 00-19: 00$ & 18:00-19:00 & NR \\
\hline & $\mathrm{P}$ & $18: 00-19: 00$ & $18: 00-19: 00$ & 18:00-19:00 & NR \\
\hline & $\mathrm{F}$ & - & - & $21: 00-22: 00$ & 18:00-19:00 \\
\hline & & & & 18:00-19:00 & 18:00-19:00 \\
\hline
\end{tabular}

NR: no biting activity recorded; I: intradomiciliary; P: peridomiciliary; F: forest activity

tected between 24:00 and 1:00 hr when the biting rate reached 79.1 per man-hr (Fig. 2).

In El Trueno the man-biting activity of $A n$. (Nys) albimanus was very low and less prolonged in comparison with that of Concherito, beginning at 19:00 and ending at 1:00 hr. A peak in the activity around houses ( 0.9 bites/man-hr) occurred between 20:00-21:00 hr. No intradomiciliary biting was recorded (Fig. 3).

The second species in importance was An. (Ker) neivai. Peridomiciliary activity in Santa Cruz began at 17:00 and ended at 21:00 hr, while at Concherito and El Trueno activity began and ended somewhat later, occurring between 18:00-22:00 hr. Maximun biting activity around houses in all three localities occurred between 18:00-19:00 hr and was greatest at Santa Cruz (up to $8.3 \mathrm{bites} / \mathrm{man}-\mathrm{hr}$ ), followed by Concherito (3.6 bites/man-hr) and El Trueno (3.0 bites/man-hr) (Figs 3, 4).

Intradomiciliary biting rates of An. (Ker) neivai

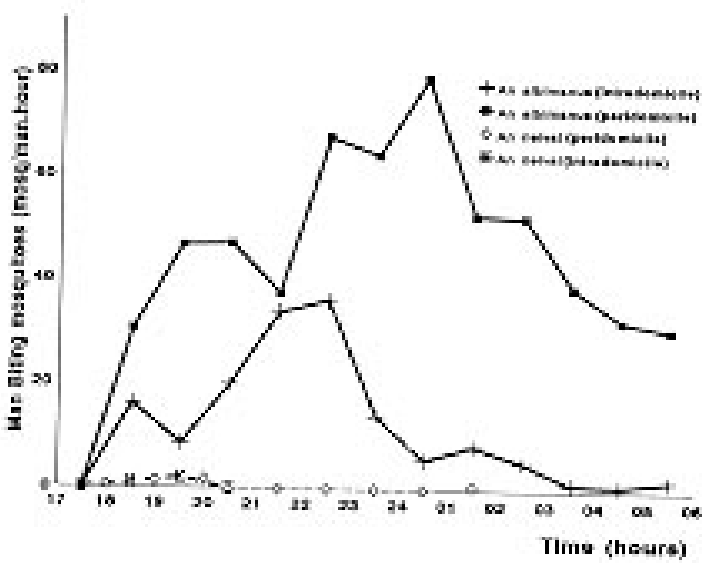

Fig. 2: mean number Anopheles mosquitoes biting/man-hour in Concherito, lower Naya River, Buenaventura, Colombia. Based on 20 sampling sessions (480 hr). were generally very low, occurring from 18:0022:00 hr. At El Trueno maximun biting activity was between 19:00-20:00 hr, when it reached 1.5 bites/man-hr. At Santa Cruz and Concherito peak activity was lower, being 0.2 and 0.8 bites $/ \mathrm{man}-\mathrm{hr}$ respectively. No intradomiciliary or peridomiciliary biting activity whatsoever was recorded for An. (Ker) neivai in La Concepción. This species demostrated sylvatic biting activity over $24 \mathrm{hr}$ (Fig. 5), a phenomenon seen in both Santa Cruz and La Concepción. In the first of these there were two biting peak, the first of 17.8 bites/man$\mathrm{hr}$ between 21:00-22:00 $\mathrm{hr}$ and the second from 18:00-19:00 hr, when a rate of 20.8 bites/man-hr was recorded. This second peak coincided with peridomociliary biting activity in Santa Cruz. At La Concepción the peaks occurred between 6:007:00 hr (4.5 bites/man-hr) and 18:00-19:00 hr (3.0 bites/man-hr). Sylvatic activity of mosquitoes was not investigated in Concherito and in El Trueno.

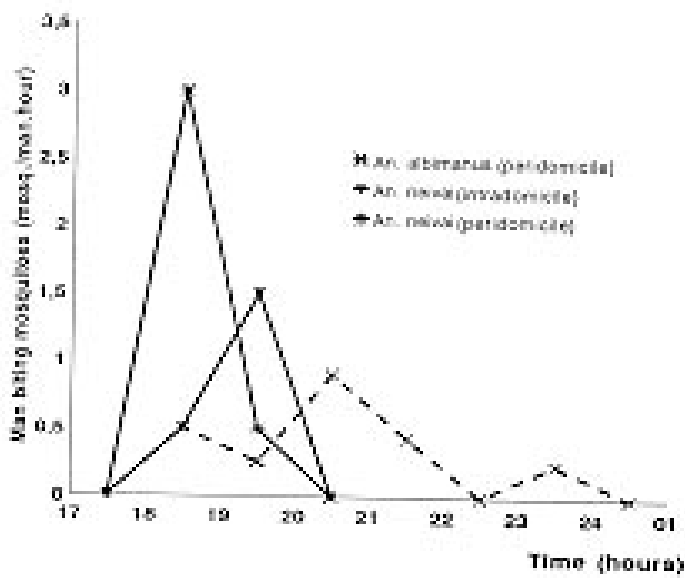

Fig. 3: mean number Anopheles mosquitoes biting/man-hour in El Trueno, lower Naya River, Buenaventura, Colombia. Based on 20 sampling sessions (480 hr). 


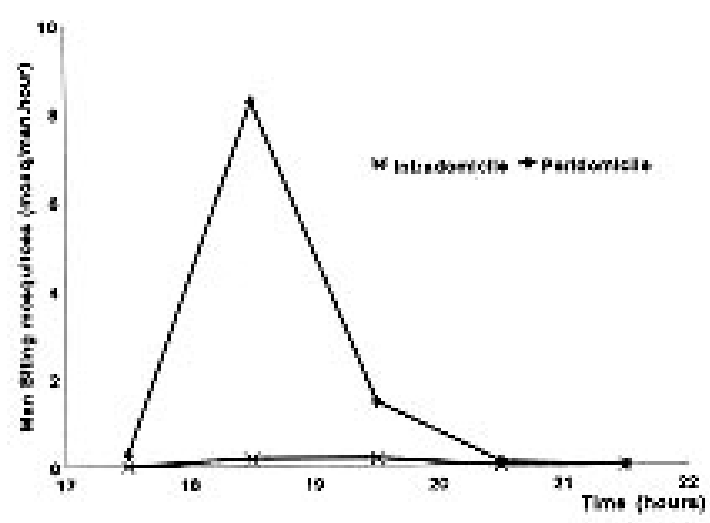

Fig. 4: mean number Anopheles neivai biting/man-hour (intradomicile and peridomicile) in Santa Cruz, lower Naya River, Buenaventura, Colombia. Based on 20 sampling sessions (480 hr).

\section{DISCUSSION}

Based on our studies it appears that the anophelines of the lower Naya River show variation with respect to their biting rates, cycles of activity and distribution. This variation in distribution is presumably related with the availability of breeding sites around the four communities studied (Hurtado \& Solarte 1986). Concherito is situated between mangroves where there is a high density of the bromeliads favoured by An.(Ker) neivai and coastal swamp which is the principal breeding habitat of An. albimanus.

An. albimanus presents a high degree of anthropophilic activity, particularly in the peridomiciliary area where $81 \%$ of mosquitoes of this species were collected. The peak of biting activity seen for this species during the present study coincides with that found by Olah and Montoya (1985) in Juanchaco and Ladrilleros, two coastal settlements near Buenaventura with similar ecological conditions to those of the lower Naya River.

The behaviour patterns seen however, differ from those observed by Quiñones et al. (1987) who did not find appreciable differences in blood-feeding activity for this species between 18.00-24.00 $\mathrm{hr}$. This discrepancy might be explained by the fact that the latter authors pooled their data from several sites on the Pacific Coast of Colombia, without taking into account ecological and climatic differences between the areas sampled.

We have insufficient data to generalize in making conclusions with respect to anopheline biting behaviour for the entire Pacific Coast of Colombia, since that the region is sub-divided into three based on ecological and climatic conditions (IGAC 1980). The most northern of these is represented

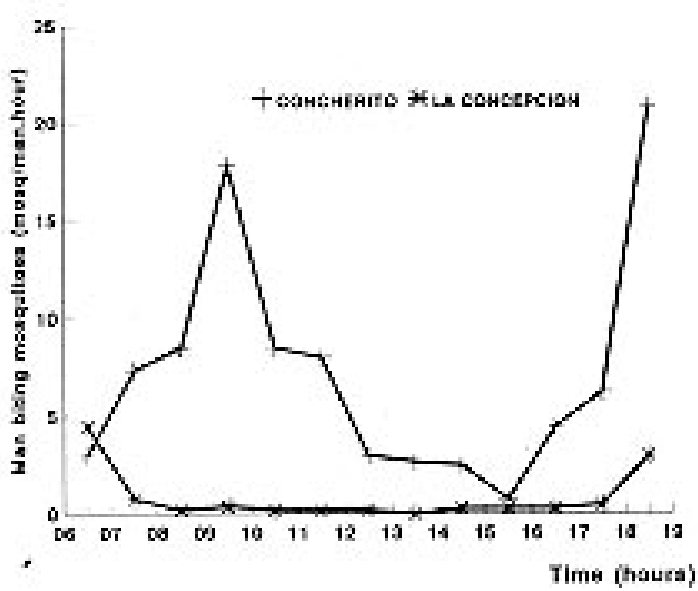

Fig. 5: mean number Anopheles neivai biting in forest/manhour in Santa Cruz and La Concepción, lower Naya River, Buenaventura, Colombia. Based on 5 sampling sessions (120 hr per site).

by the Department of Chocó and has the highest rainfall and lowest temperatures. The southermost subregion (in Deparment of Nariño) is driest and has higher temperatures while the central subregion (coast of the Departments of Valle and Cauca) is intermediate between the other two respect to temperature and rainfall. These differences may influence anopheline biting behaviour in the three subregions.

Comparison of the intradomiciliary and peridomiciliary biting activity of An. (Nys) albimanus suggest that this species is more exophagous than endophagous, since only $19 \%$ of the mosquitoes of this species sampled were collected indoors (Fig. 2). Based on comparison between the biting rates of this species observed in Concherito and El Trueno, it appears that there is a gradient with respect to the numbers of mosquitoes captured from the coast towards the interior on the lower Naya River, perhaps governed by the availability of suitable larval habitats. The apparent absence of An. (Nys) albimanus in Santa Cruz may be explained by the paucity of larval habitats.

Although An. (Nys) albimanus is absent from La Concepción, the area appears to contain habitat suitable for this species. Its absence might be explained by the dense forest, broken only by narrow river courses, which sorrounds this settlement and perhaps acts as a barrier to colonization. In studies performed in Mexico, Savage et al. (1990) detected a negative correlation between An. (Nys) albimanus population levels and altitude, a similar phenomenon was seen during the present study for An. (Nys) albimanus.

Blood-feeding activity of An. (Ker) neivai as determined during this study was similar to that 
seen by Olah and Montoya (1985) in Juanchaco and Ladrilleros, although in the latter sites it ended at $1.00 \mathrm{hr}$. Highest biting rate of this species was seen in El Trueno, where the population is more endophagic than in other areas, perhaps because the breeding sites are situated close to the houses. Nevertheless An. (Ker) neivai is clearly more exophagic than endophagic, the percentage of mosquitoes captured indoors being only $27.9 \%$, the remainder specimens were collected around the settlements and in forest. The evening peak of activity of the An. (Ker) neivai coincides with the time at which members of the community sit outside their houses to converse at the end of the working day. This may explain why indoor collections of An. (Ker) neivai were so low at this time. Astaiza et al. (1988) reported that the intradomiciliary activity of this species on the Pacific Coast of Colombia is low compared with that of outdoors and with the fact that biting occurs through the night, from 19:00-5:00 hr.

Sylvatic biting activity of An. (Ker) neivai during the day shows a bimodal patterns. This differs from the findings of Pajot et al. (1978) in French Guiana, where this species shows two peaks of activity, one in the morning between 10:30 and 11:30 $\mathrm{hr}$ and the other in the afternoon between 15:00-16:00 hr. Working in Charambirá (another locality on the Pacific Coast of Colombia), Astaiza et al. (1988) encountered a statistically significant difference between samples captured in the two peaks, those collected in the morning containing a higher proportion of parous females. Murillo et al. (1988) demostrated that biting behavior of this species is determined primarily by light intensity, ranging between 0.1 and 10 lux and reaching a maximum at close to 3 lux.

The sylvatic activity of An. (Ker) neivai in the lower Rio Naya occurs over $24 \mathrm{hr}$. Lee and Sanmartin (1967) and later Barreto and Lee (1969) observed the abundance and circadian activity on the Rio Raposo, again in the Buenaventura area. Trapido and Galindo (1957) found that this species was active during the day in the canopy of the rain forest and at ground level in deciduous forest in Panamá.

Valderrama and Santander (1985) carried out an epidemiological study at Bajo Calima, a settlement about $10 \mathrm{~km}$ from Buenaventura. They found that $83 \%$ of malaria cases in the area had been acquired outdoors. The relative risk of contracting malaria by diurnal exposure outdoors was always higher when compared with peridomiciliary and nocturnal exposure. The biting habits of An. (Ker) neivai would explain this phenomenon. The transmission rate of malaria in the area corresponds to one infective bite by this species per man per week
(Alzate, pers. comm.).

Human activity and commerce on the Naya River occurs across a variety of ecological situations with traffic by fishermen and other members of the population enabling the malaria parasite to diffuse through the area. Although the human biting rate of An. (Ker) neivai is less than An. (Nys) albimanus both species may play a role in the spread of malaria.

\section{ACKNOWLEDGEMENTS}

To Alberto Alzate, Marco Fidel Suarez and Paulina Fajardo for criticizing the manuscript. To Dr José Vicente Scorza for suggestions and Michel Alberico and Inge Armbrecht for reviewing the manuscript.

\section{REFERENCES}

Astaiza R, Murillo C, Fajardo P 1988. Biología de Anopheles (Kerteszia) neivai Howard, Dyar \& Knab, 1913 (Diptera: Culicidae) en la Costa Pacífica de Colombia. II Flutuación de la población adulta. Rev Saúde Públ 22: 101-108.

Barreto P, Lee VH 1969. Artrópodos hematófagos del Río Raposo, Valle del Cauca, Colombia. I. Culicidae. Caldasia 10: 407-440.

Beck SD 1968. Insect photoperiodism. Academic Press, New York and London, viii +288 pp.

Carvajal H, de Herrera MH, Quintero J, Alzate A, Herrera S 1989. Anopheles neivai: a vector of malaria in the Pacific Lowland of Colombia. Trans R Soc Trop Med Hyg 83: 609.

Cova GP, Sutil E 1977. Clave gráfica para la clasificación de Anopheles de Venezuela. Publ Div Endem Rural Direc Malariol Saneam Amb. Ministerio de Sanidad y Asistencia Social, Maracay, Venezuela, $160 \mathrm{pp}$.

Faran ME 1980. Mosquito Studies (Diptera: Culicidae) XXXIV. A revision of the albimanus section of the subgenus Anopheles Nissorhynchus (Diptera, Culicidae). Am Ent Inst 15: 1-215.

Faran ME, Linthicum KJ 1981. A Handbook of the Amazonian species of Anopheles (Nyssorhynchus) (Diptera, Culicidae). Mosq Syst 13: 1-181.

Herrera SV, Suarez MF, Sánchez GI, Quiñones ML, de Herrera M 1987. Uso de la técnica inmunoradiométrica (IRMA) en Anopheles de Colombia para la identificación de esporozoitos de Plasmodium. Colombia Med 18: 2-6.

Huffaker CB, Soto H, Rey H 1945. Additional wild cought Anopheles punctimacula Dyar \& Knab infected with malaria plasmodia in Colombia, South America. Am J Hyg 42: 107-110.

Hurtado JC, Solarte Y 1986. Interrelación entre la vegetación y las poblaciones de anofelinos presentes en la parte baja del Rio Naya, Buenaventura, Colombia. Undergraduate Thesis in Biology, University of Valle, Cali, Colombia, xxiv + 189 pp.

IGAC-Instituto Geográfico Agustin Codazzi 1980. Estudio general de suelos del Municipio de Buenaventura. Bogotá D.E. xv +277 pp.

Lee VH, Sanmartin C 1967. Isolations of Guarao virus 
from Anopheles $(\mathrm{Ke})$ neivai in the pacific low lands of Colombia. Am J Trop Med Hyg 16: 778-781.

Murillo C, Astaiza R, Fajardo P 1988. Biología de Anopheles (K) neivai Howard, Dyar \& Knab, 1913 (Diptera: Culicidae) en la Costa Pacífica de Colombia. III. Medidas de luminosidad y el comportamiento de picadura. Rev Saúde Publ 22: 109-112.

Olah CAM, Montoya J 1985. Variación estacional en la actividad de picadura al hombre por anofelinos en Juanchaco y Ladrilleros, Buanaventura. Undergraduate Thesis in Biology, University of Valle, Cali, Colombia, xv +121 pp.

Pajot FX, Molix JF, Lepond F 1978. Anopheles et paludisme sur le Haut-Oyapock (Guyane françoise) Ser Entomol Med Parasitol 6: 105-111.

Quiñones ML, Suarez MF, Fleming G 1987. Distribución y bionomía de los anophelinos de la Costa Pacífica de Colombia. Colombia Med 18: 19-24.

Rengifo S 1974. Informe del médico de sanidad Departamental en Puerto Merizalde, Cajambre, Naya y Yurumangui. Cespedesia 111: 11-12.

Rey M, Soto H, Huffaker CB 1945. Anopheles punctimacula Dyar \& Knab as the vector of malaria in Medellin, Colombia. South America. Am J Trop Med 25: 502-505.

Savage HM, Rejmankova E, Arredondo-Jimenez JJ, Roberts DR, Rodriguez MH 1990. Limnological and botanical characterization of larval habitats for two primary malarial vectors, Anopheles albimanus and Anopheles pseudopunctipennis, in coastal areas of Chiapas State, México. J Am Mosq Control Assoc 6: 612-620.

Solarte Y, González R, Hurtado JC, Alzate A 1994. Influencia de la vegetación en la presencia, distribución y abundancia de criaderos de tres especies de Anopheles (Diptera: Culicidae) en la parte baja del Rio Naya, Costa Pacífica de Colombia. Bol Mus Entomol Univ Valle 2: 55-93.

Trapido H, Galindo P 1957. Mosquitoes associated with jungle yellow fever near Almirante, Panama. Am J Trop Med Hyg 6: 114-144.

Valderrama FG, Santander AG 1985. Riesgo de infección extradomiciliar de la malaria en diferentes ámbitos sociológicos ocupacionales en Bajo Calima, Buenaventura, Colombia. Master's Thesis in Epidemiology, University of Valle, Cali, Colombia, iv $+191 \mathrm{pp}$.

WHO 1975. Manual on Practical Entomology in Malaria: Part 1. Vector bionomics and organization of antimalaria activities. No. 13, Genova, 191 pp.

Zavortink T 1973. Mosquitoes Studies (Diptera, Culicidae) XXXIX. A review of the Subgenus Kerteszia of Anopheles. Contr Am Ent Inst Ann Arbor 9: 1-54. 